\title{
PENENTUAN ARAH TEGASAN PEMBENTUK KEKAR MENGGUNAKAN DIAGRAM ROSETTE (STUDI KASUS DAERAH PATTONGTONGAN, SULAWESI SELATAN)
}

\author{
Dewi Ainun Jariah, Ismira Luthfia, Nurita Dwi Puspita S., Muh. Rexy Syam, Deviana Frindy R, Hanifah \\ Hamdah, Nuraisyiah Pertiwi K., Muh. Fazlur Rahman, William Maesalangi, Muhammad Altin Massinai, \\ Muhammad Fawzy Ismullah Massinai \\ Program Studi Geofisika, Fakultas Matematika dan Ilmu Pengetahuan Alam, Universitas Hasanuddin \\ e-mail : altin@science.unhas.ac.id
}

\begin{abstract}
Abstrak. Struktur geologi adalah gambaran bentuk arsitektur batuan penyusunan kerak bumi akibat sedimentasi dan deformasi. Dalam melakukan identifikasi geologi suatu wilayah, salah satu faktor utama yang harus dipertimbangkan adalah struktur geologi, yang umumnya mengacu kepada data-data primer berupa data observasi lapangan maupun data sekunder. Penelitian yang dilakukan di Desa Pattontongan Kecamatan Mandai Kabupaten Maros Sulawesi Selatan ini mengkhususkan pada penentuan arah tegasan utama di daerah tersebut. Penelitian ini menggunakan data lapangan berupa data strike dan data dip. Penentuan arah tegasan dengan analisis kekar menggunakan analisa Diagram Rosette. Hasil yang didapatkan berupa arah tegasan maksimum berarah timur laut-barat daya. Hal ini disebabkan proses pembentukan kekar pada Desa Pattongtongan dipengaruhi proses vulkanisme pada pembentukan Formasi Camba.
\end{abstract}

Kata Kunci: diagram rosette, kekar; struktur; tegasan

\begin{abstract}
Geological structure is a description of the architectural forms of rock composing the crust due to sedimentation and deformation. In carrying out geological identification of a region, one of the main factors that must be considered is the structure, which generally refers to primary data such as field observation data and secondary data. Research conducted in Pattontongan Village, Mandai Subdistrict, Maros Regency, South Sulawesi, specializes in determining the direction of the main stresses in the area. This research uses field data in the form of strike and dip. Stress direction determination with robust analysis using a Rosette Diagram. The results obtained in the form of maximum stress direction trending northeast-southwest. This is due to the formation of the fractures formed process in Pattongtongan Village is influenced by the volcanism in the Camba Formation.
\end{abstract}

Keywords: rosette diagram; fracture; structure; stress

\section{PENDAHULUAN}

Geologi struktur adalah bagian dari ilmu geologi yang mempelajari tentang bentuk batuan sebagai hasil dari proses deformasi (Noor, 2012). Deformasi yang dimaksud pada pengertian di atas lebih menekankan pada perubahan bentuk dan ukuran pada batuan yang disebabkan oleh gaya yang berasal dari bawah permukaan bumi. Secara sederhananya, geologi struktur adalah ilmu yang mempelajari struktur geologi.

Struktur dalam geologi ada tiga buah yaitu kekar, sesar dan lipatan. Terdapat banyak kekar pada singkapan batuan di daerah Desa Pattongtongan, Kecamatan Mandai, Kabupaten Maros, Sulawesi Selatan yang berada di sepanjang jalan dan dekat perumahan warga. Banyaknya tegasan yang merupakan gaya tektonik tentu mempengaruhi keadaan ini. Hal inilah yang menjadi titik tolak penelitian ini. Penelitian ini berupa studi lapangan dan studi literatur. Penelitian ini bertujuan untuk menganalisa tegasan maksimum yang bekerja pada pembentukan kekar di Desa Pattongtongan, Kecamatan Mandai, Kabupaten Maros, Sulawesi Selatan.

Kekar pada batuan adalah kenampakan rekahan atau retakan yang disebabkan oleh gaya yang bekerja pada batuan tersebut dan belum mengalami pergeseran. Ciri umumnya berupa pemotongan bidang perlapisan batuan, yang dalam proses berikutnya terisi mineral lain.

Pengertian lainnya adalah ketidaksambungnya yang terbentuk alami pada batuan, yang disebabkan 
oleh deformasi atau diagenesa fisik (Sapiie dkk., 2017). Kekar dapat terbentuk karena beberapa faktor seperti temparatur, tekanan fluida dalam pori, laju rengan dan tegasan (G.J. Borradaile, 2014) . Kekar terbentuk dari 3 buah tegasan yang berasal dari gaya tektonik. Tegasan tersebut ditandai oleh $\sigma_{1}$ sebagai tegasan maksimum, $\sigma_{2}$ dan $\sigma_{3}$ sebagai tegasan minimum seperti pada Gambar 1.

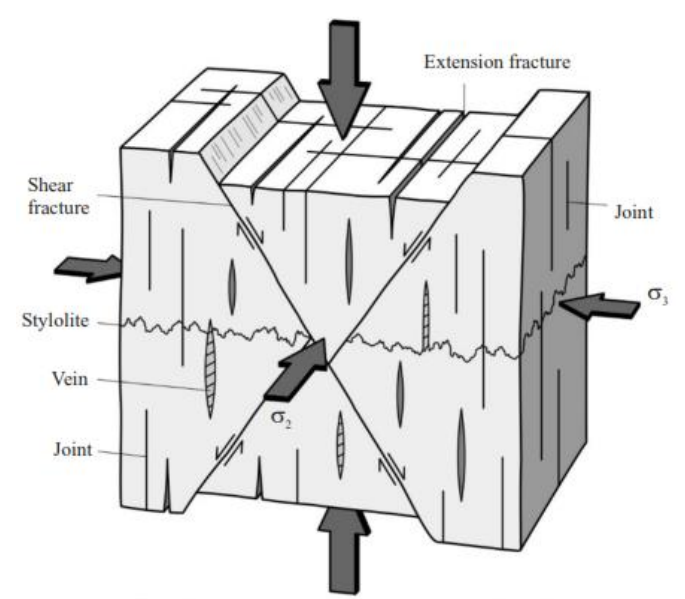

Gambar 1 Penampang tegasan dan fracture (Sapiie dkk., 2017)

Berdasarkan arah gerakan, kekar pada batuan diklasifikasikan menjadi extension and shear fracture. Shear fracture ditandai oleh pergerakan sejajar dari bidang kekar, sedangkan extension fracture bergerak tegak lurus dengan bidang kekar (Sapiie dkk., 2017).

Shear fracture memiliki ciri rekahan yaitu dijumpai berpasang-pasangan, arahnya sejajar, dan mempunyai bidang bidang kekar yang rata. Kekar ini terdiri atas kekar tarik dan kekar gerus. Kekar tarik bentuk berpasangan, permukaannya kasar, berbentuk seperti kotak dan jajargenjang, serta mempunyai bukaan kekar yang besar. Kekar gerus mempunyai ciri-ciri berupa bentuk kekarnya yang membentuk garis horisontal, mempunyai bukaan kekar yang kecil, serta permukaan yang licin karena sering terjadi gerusan.

DIPS adalah program yang dirancang untuk menganalisis struktur geologi (Massinai, M.A. dkk., 2015). Perangkat lunak ini didasari oleh proyeksi stereografik yang menggambarkan arah tegasan dari data strike dan dip sebagai data geologi stuktur.

DIPS digunakan untuk berbagai macam kepentingan. Selain pada bidang geologi, DIPS juga sering digunakan pada bidang pertambangan dan teknik sipil. Aplikasi ini mampu menganalisis struktur batuan yang berasal dari berbagai jenis orientasi basis data. Pada penelitian ini, DIPS digunakan untuk penentuan arah tegasan dengan menggunakan Diagram Rosette.

Dua fungsi utama DIPS, adalah:

1. Spreadsheet atau lembar kerja yang dapat diatur sedemikian rupa sebagai data masukan. Fungsi ini terdiri dari kolom dan baris.

2. Plot pada DIPS ada banyak sesuai jenis dan tampilan yang diinginkan yaitu Pole, Contour, Scatter, Rosette, dan Major Planes Plot.

\section{Geologi Regional}

Singkapan batuan dan interpretasi geofisika memperlihatkan bentuk struktur yang berbeda dari berbagai tempat. Urutan sederhana pembentukan bentuk tersebut mengikuti pola yang dimulai dari gaya tegasan dan diakhiri oleh deformasi batuan. Deformasi pada batuan dapat berbentuk lipatan maupun patahan/ sesar (Noor, 2012).

Daerah Sulawesi Selatan merupakan salah satu daerah yang menarik menurut tatanan struktur geologinya. Daerah ini terdiri dari Satuan Batuan Gunungapi Formasi Carnba, Formasi Walanae, Satuan Intrusi Basal, Satuan Batuan Gunungapi Lompobatang dan Endapan aluvial, Rawa, dan Pantai (A.F. Sompotan, 2012).

Daerah penelitian terletak di Formasi Camba. Formasi Camba berada di sepanjang bagian barat Sulawesi Selatan dan terdiri atas batuan vulkanik seperti breksi vulkanik, aglomerat, lava dan tuf yang berselingan dengan batuan sedimen laut. Formasi ini mungkin berhubungan dengan subduksi sebelumnya di Miosen Awal saat pemekaran intraplate (Sapiie dkk., 2017). Formasi ini berumur Miosen Tengah-Miosen Akhir, terdiri dari produk vulkanik seperti aglomerat, breksi gunungapi, dan tufa halus hingga batuan lapili.

\section{METODOLOGI}

Artikel diterima 12 Februari 2019, Revisi 20 Februari 2019 Online 30 April 2019 
Penelitian ini dilakukan di Desa Pattongtongan, Kecamatan Mandai, Kabupaten Maros, Sulawesi Selatan. Alat yang digunakan utamanya berupa kompas geologi dan GPS. Proses akuisisi data dilakukan dengan mengukur nilai strike dan dip di sepanjang lokasi pengukuran. Pengolahan data dilakukan melalui program DIPS untuk mencari arah tegasan yang berbentuk Diagram Rosette.

\section{HASIL DAN PEMBAHASAN}

Jenis kekar yang ditemukan pada daerah penelitian adalah shear fracture (Gambar 2). Jenis kekarnya adalah kekar gerus. Kekar gerus mempunyai ciri-ciri di lapangan seperti membentuk garis horisontal, permukaan relatif licin dan mempunyai bukaan kekar yang kecil.

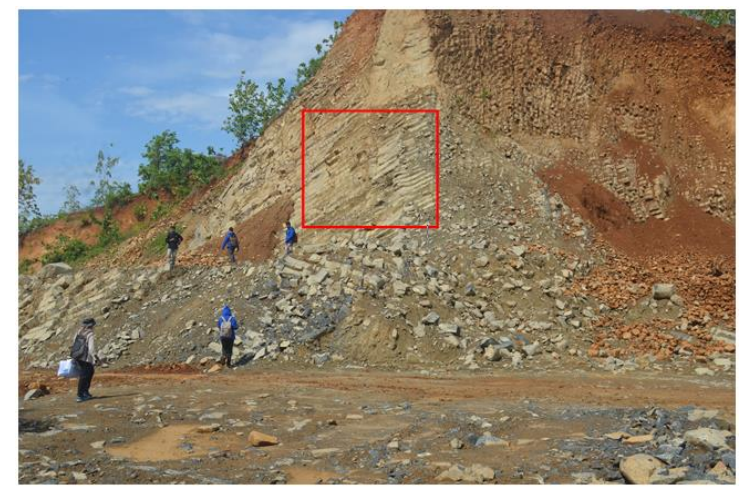

Gambar 2 Penampakan shear fracture (kotak merah) pada daerah penelitian

Berdasarkan data strike dan dip yang diperoleh dari lapangan pada Tabel 1 dapat dihasilkan Diagram Rosette. Data strike dan dip tersebut dimasukkan ke dalam program DIPS sehingga dapat ditentukan tegasan maksimum $(\sigma 1)$, dan tegasan minimum ( $\sigma 2)$, serta arah tegasannya.

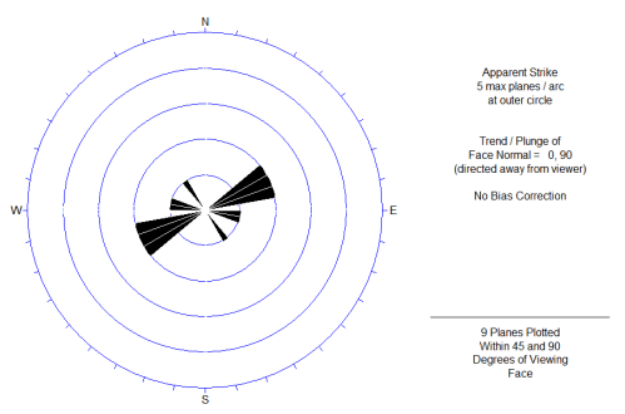

Gambar 3 Diagram Rosette memperlihatkan tegasan utama berarah Timur Laut - Barat Daya
Tabel 1. Data Observasi Lapangan

\begin{tabular}{lll}
\hline No & Strike & Dip \\
\hline 1 & 329 & 54 \\
2 & 253 & 85 \\
3 & 289 & 78 \\
4 & 247 & 8 \\
5 & 258 & 89 \\
6 & 244 & 51 \\
7 & 238 & 75 \\
8 & 236 & 68 \\
9 & 270 & 88 \\
\hline
\end{tabular}

Diagram Rosette pada Gambar 3 menunjukkan arah strike kekar di Desa Pattongtongan, Kecamatan Mandai, Kabupaten Maros, Sulawesi Selatan yang berarah Timur Laut-Barat Daya dan Barat LautTenggara. Tegasan utama didominasi ke arah Timur Laut-Barat Daya.

Tegasan utama yang menunjukkan arah tersebut disebabkan karena pembentukan Formasi Camba yang didominasi oleh aktivitas vulkanik. Hal ini dapat dilihat pada kenampakan kelurusan di daerah tersebut di lapangan yang nampak teratur yang sesuai dengan arah tegasan maksimum (Paguican dan Bursik, 2016).

Pengaruh lain adalah tektonik dengan ciri kerak yang terbuka berarah tegak lurus dengan arah tegasan maksimum (Paguican dan Bursik, 2016). Pengaruh tektonik disebabkan Formasi Camba yang berumur Tersier. Morfologi yang berbentuk huruf $\mathrm{V}$ (geomorfik muda) dengan tegasannya terlihat banyak dan tidak teratur menunjukkan tektonik yang aktif. Sementara saat geomorfologinya berbentuk huruf $U$ (geomorfik tua) dengan arah tegasan yang cukup teratur menunjukkan tektonik yang tidak aktif.

\section{PENUTUP}

\section{Simpulan dan Saran}

Kekar yang terlihat di daerah penelitian, Desa Pattongtongan, Kecamatan Mandai, Kabupaten Maros, Sulawesi Selatan, adalah shear fractures. Ini ditandai oleh kenampakannya yaitu dijumpai berpasang-pasangan, arahnya sejajar, dan mempunyai bidang bidang kekar yang rata. Kekar ini terdiri atas kekar gerus. Berdasarkan Diagram 
Rosette, tegasan utama pembentukan kekar pada daerah penelitian berarah Timur Laut-Barat Daya. Selain faktor tektonik, faktor aktivitas vulkanik sebagai pembentuk Formasi Camba diduga sebagai penyebar arah tegasan maksimum yang bekerja di Desa Pattongtongan, Kab. Maros, Sulawesi Selatan.

Hasil yang didapatkan sedianya dapat menjadi penentian lebih lanjut menggunakan data geofisika guna mengetahui struktur geologi di bawah permukaan.

\section{Ucapan Terima Kasih}

Penulis mengucapkan terima kasih kepada seluruh pihak yang telah membantu penelitian ini, khususnya pada Departemen Geofisika Universitas Hasanuddin dan masyarakat Desa Pattongtongan, Kecamatan Mandai, Kabupaten Maros, Sulawesi Selatan.

\section{DAFTAR PUSTAKA}

A.F. Sompotan (2012), Struktur Geologi Sulawesi, Institut Teknologi Bandung, Bandung.

G.J. Borradaile (2014), Understanding Geology Through Maps, Elsevier. http://doi.org/10.1016/C2013-018872-1.

Massinai, M.A., Alimuddin, R.A.M. dan Maria (2015), "Analisis Arah Kekar Parangloe Sulawesi Selatan dengan Menggunakan Program DIPS", Prosiding SNFMKS-2015,

Noor, D. (2012), Google-Books-ID: TRdADAAAQBAJ, Pengantar Geologi, Deepublish, Universitas Pakuan.

Paguican, E.M.R. dan Bursik, M.I. (2016), "Tectonic Geomorphology and Volcano-Tectonic Interaction in the Eastern Boundary of the Southern Cascades (Hat Creek Graben Region), California, USA", Frontiers in Earth Science, Vol.4. http://doi.org/10.3389/feart.2016.00076.

Sapiie, B., Aziz Nugraha, M., Kurniawan Wardana, R. dan Rifiyanto, A. (2017), "Fracture Characteristics of Mélange Complex Basement in Bantimala Area, South Sulawesi, Indonesia", Indonesian Journal on Geoscience, Vol.4, No.2, hal. 121-141. http://doi.org/10.17014/ijog.4.3.121-141. 